\title{
Experience of Online Learning the Elective Course "Competency-Based Approach in Pharmacy Education" in Bogomolets National Medical University
}

\author{
Tetiana Reva, Yaroslava Pushkarova, and Oksana Chkhalo
}

\section{ABSTRACT}

The article focuses on the experience of online learning the elective course "Competency-based approach in Pharmacy education" for pharmacy students of the first year of study at the Bogomolets National Medical University. Course was designed to discuss actual information on the development of competency-oriented higher pharmaceutical education in Ukraine and increase Ukrainian students' understanding of actual role of the pharmacist as health care professional. The 3.2-credit hours elective course consisted of five lectures (ten hours), ten seminars (twenty hours) and independent work of students (sixty-six hours). The article represents information about the structure of the course and its online form organizing due to the COVID-19 pandemic in 2020/2021 academic year. There were 162 students enrolled in this course. The course was evaluated using student evaluation survey. Overall, students felt that the course was educational, engaging, and well organized with effective delivery of material. This elective course was successfully conducted achieving the high level learning outcomes and was well received by the students.

Keywords: Competency, distance learning, education, elective course, pharmacist.
Published Online: November 16, 2021

ISSN: $2736-4534$

DOI : 10.24018/ejedu.2021.2.6.181

\section{T. Reva}

Bogomolets National Medical University, Kyiv, Ukraine.

(e-mail: revatd@ukr.net)

Y. Pushkarova*

Bogomolets National Medical

University, Kyiv, Ukraine.

(e-mail:

yaroslava.pushkarova@gmail.com)

O. Chkhalo

Bogomolets National Medical

University, Kyiv, Ukraine.

(e-mail: ochkhalo@ukr.net)

*Corresponding Author

\section{INTRODUCTION}

Today, the Ukrainian pharmaceutical market is a fastgrowing. The development of the pharmaceutical sector in Ukraine is characterized by an increasing the share of science-intensive, high-tech products regarding international standards. The current challenges facing the Ukrainian healthcare and pharmaceutical sector include ensuring a high level of quality and effectiveness of pharmacotherapy and disease prevention, developing human potential, increasing global competitiveness in the world market of pharmaceutical services. In view of this, the implementation of the competency-based approach in the teaching of future pharmacists in modern higher medical educational institutions is focused on formation of current set of specific competencies that relate to the qualitative professional performance (Panfilova et al., 2018; Eiben et al., 2021; Dorovsky \& Oliynyk, 2014). So, the main driver for adopting competency-based educational designs is the need to prepare pharmacists for their societal role, ultimately leading to improvement of health care and patient safety (Koster et al., 2017).

In the pharmacy literature, the "term" competency refers to a set of abilities, knowledge, attitudes, skills and beliefs gained by individuals from education, training and clinical experience, which enable them to practice effectively in the pharmacy profession (Hager \& Gonczi, 1996; Katoue \& Schwinghammer, 2020).

The specificity of the educational process for the training of competent pharmacy specialists in Ukrainian medical universities at the present stage of development of the pharmaceutical sector is largely mediated by real political and socio-economic processes, such as, Ukraine's integration into the world community, global structural processes in economy, need to use the resources of the health care system and the pharmaceutical sector to provide the population with medicines for affordable and effective pharmacotherapy and disease prevention (Reva, 2016).

The traditional role of the pharmacist in supplying drugs needs to be expanded to a health care professional. The pharmacist should be capable of consolidating his solid scientific education with the practical integration of knowledge (Sinha, 2014; Toklu \& Hussain, 2013).

The elective course "Competency-based approach in Pharmacy education" is designed for students of the first year of study of the pharmaceutical faculty at the Bogomolets National Medical University (Reva, 2017). The aims of this paper are to describe the curriculum of the elective course, its online form organizing and assess the attitude of students to the course. 


\section{MEthods}

\section{A. Description of Elective Course}

The 3.2-credit hours elective course "Competency-based approach in Pharmacy education" was offered during the first semester 2020/2021 academic year. There were 162 students enrolled in this course. The course consisted of five lectures (ten hours), ten seminars (twenty hours) and independent work of students (sixty six hours).

The primary goal of the course was to provide future pharmacists with up-to-date information on the development of competency-oriented higher pharmaceutical education in Ukraine. The objectives of the course are to:

1) discuss the current tasks of development of competencyoriented higher pharmaceutical education at the present stage in a process of European integration,

2) analyze the modern regulatory and legal support of the pharmaceutical health care sector of Ukraine, its compliance with international, in particular European legislation,

3) get acquainted with the list of competencies of a pharmacist in accordance with the Standard of Higher Education of Ukraine of knowledge 22 "Health care" specialty 226 "Pharmacy, industrial pharmacy", 2018,

4) offer recommendations for improving the Code of Pharmaceutical Ethics from the standpoint competencyoriented higher pharmacy education and taking into account the new policy of its development.

According to the curriculum, seminars provide for the formation of students' knowledge, skills and abilities of acquaintance with domestic and world discourse of development of pharmaceutical branch; analysis of priorities of the higher pharmacy education development in the context of the main trends of modern development of the industry; analytical review of standards, rules, norms concerning the system of ensuring the educational policy of Ukraine in the field of pharmacy for the period of independence; analysis of perspective strategy of the state policy of Ukraine on the development of the pharmaceutical industry; prediction by students of scientifically substantiated approaches to reforming the domestic system of pharmaceutical industry, taking into account the professional competencies formed during study of course topics (Table I).

As a result of learning the elective course future pharmacists will develop the abilities and skills such as:

1) specialized knowledge, which is the basis for the formation of professional specialist thinking,

2) ability to solve complex situational tasks and problems of a professional nature, that needs updating and integration of knowledge on pharmacy,

3) communication skills that provides a clear and unambiguous presentation of their own conclusions, as well as knowledge and explanations in the process of educational and professional information exchange,

4) ability to solve professional tasks and problems independently and be responsible for their results.

Student's performance was evaluated through case studies, guided discussions, writing of case essays, presentations preparation, answering the questions and simulated scenarios of different situations which may occur in the pharmacists' work (Table I).

TABLE I: STUDENT ACTIVITIES DURING THE COURSE

\begin{tabular}{|c|c|c|c|}
\hline $\mathrm{N}$ & Topic & Task for students & In-class activity \\
\hline 1 & $\begin{array}{l}\text { Competency-based approach as a paradigm of } \\
\text { modern higher pharmacy education, its basic } \\
\text { concepts and categories. }\end{array}$ & Acquaint with the corresponding literature. & $\begin{array}{l}\text { Discussion, answering the questions, } \\
\text { expression of one's own opinion. }\end{array}$ \\
\hline 3 & $\begin{array}{l}\text { Competency as a structural component of self- } \\
\text { realization of the pharmacist individual: } \\
\text { sources and driving forces of development. }\end{array}$ & $\begin{array}{l}\text { Acquaint with the corresponding literature, } \\
\text { writing of essay about the dominant } \\
\text { competencies for individual development. }\end{array}$ & $\begin{array}{l}\text { Discussion, answering the questions, } \\
\text { presentation of essays, expression of } \\
\text { one's own opinion. }\end{array}$ \\
\hline 4 & $\begin{array}{c}\text { "Competency" idea in higher pharmacy } \\
\text { education abroad: successes and problems of } \\
\text { implementation. }\end{array}$ & $\begin{array}{l}\text { Acquaint with the corresponding literature, } \\
\text { preparation of presentation about } \\
\text { "competency" idea in education abroad. }\end{array}$ & $\begin{array}{l}\text { Discussion, showing of presentations, } \\
\text { answering the questions, expression of } \\
\text { one's own opinion. }\end{array}$ \\
\hline 5 & $\begin{array}{l}\text { Competency-based model of the } \\
\text { pharmaceutical sector development as a } \\
\text { necessary condition for effective functioning of } \\
\text { health care industry. }\end{array}$ & Acquaint with the corresponding literature. & $\begin{array}{l}\text { Discussion, answering the questions, } \\
\text { expression of one's own opinion. }\end{array}$ \\
\hline 6 & $\begin{array}{c}\text { Competency-based approach in education: } \\
\text { practical aspect. }\end{array}$ & Acquaint with the corresponding literature. & $\begin{array}{l}\text { Discussion, answering the questions, } \\
\text { expression of one's own opinion. }\end{array}$ \\
\hline 7 & $\begin{array}{l}\text { Knowledge as the core of the competency- } \\
\text { based approach in higher pharmacy education. }\end{array}$ & $\begin{array}{l}\text { Acquaint with the corresponding literature, } \\
\text { writing of essay about the knowledge which is } \\
\text { required for pharmacist work. }\end{array}$ & $\begin{array}{l}\text { Discussion, answering the questions, } \\
\text { presentation of essays, expression of } \\
\text { one's own opinion. }\end{array}$ \\
\hline 8 & $\begin{array}{l}\text { Ability to manage conflicts is a sign of a } \\
\text { socially competent personality of pharmacist. }\end{array}$ & $\begin{array}{l}\text { Acquaint with the corresponding literature, } \\
\text { preparation of presentation about one of the } \\
\text { probability conflicts in real pharmacists' work. }\end{array}$ & $\begin{array}{l}\text { Discussion, showing of presentations, } \\
\text { simulated scenarios of probability } \\
\text { conflicts in pharmacists work, expression } \\
\text { of one's own opinion. }\end{array}$ \\
\hline 9 & $\begin{array}{c}\text { Methods of forming the subject competency of } \\
\text { students of specialty } 226 \text { "Pharmacy, industrial } \\
\text { pharmacy" in the process of teaching analytical } \\
\text { chemistry. }\end{array}$ & $\begin{array}{c}\text { Acquaint with the corresponding literature, } \\
\text { choose any topic in analytical chemistry and } \\
\text { describe the required competencies for its } \\
\text { successful studying. }\end{array}$ & $\begin{array}{l}\text { Discussion, answering the questions, } \\
\text { presentation of works about choosing } \\
\text { topics, expression of one's own opinion. }\end{array}$ \\
\hline 10 & $\begin{array}{c}\text { Methods of forming the subject competency of } \\
\text { students of specialty } 226 \text { "Pharmacy, industrial } \\
\text { pharmacy" in the process of teaching inorganic } \\
\text { chemistry. }\end{array}$ & $\begin{array}{c}\text { Acquaint with the corresponding literature, } \\
\text { choose any topic in analytical chemistry and } \\
\text { describe the required competencies for its } \\
\text { successful studying. }\end{array}$ & $\begin{array}{l}\text { Discussion, answering the questions, } \\
\text { presentation of works about choosing } \\
\text { topics, expression of one's own opinion. }\end{array}$ \\
\hline
\end{tabular}




\section{B. Organizing Online Course}

Online form and blended form of education were adopted in Bogomolets National Medical University due to the COVID-19 pandemic in 2020/2021 academic year. Bogomolets National Medical University has implemented the platform LIKAR_NMU (https://likar.nmuofficial.com/mc/index.php/usr/login/login) on the basis of Learning Management Systems Moodle for distance education for the period of quarantine (Kuchyn et al., 2021). LMS such as Moodle is a great repository of materials and has a great potential. LMS is used in higher educational system to improve the teaching and learning experience (Widyaningsih et al., 2021; Aldiab et al., 2019; De Mario et al., 2020).

The using portal LIKAR_NMU allows creating a wellstructured teacher-student interaction. All useful materials were posted on a web-based learning platform LIKAR_NMU. Let's describe course blocks more detailed.

Part "General information about discipline" of online course includes pdf-files of education curriculum, calendarthematic plan of seminars and calendar-thematic plan of lectures. This information is important for students and help them hit their goals and targets in line with course curriculum in "Competency-based approach in Pharmacy education".

Part "Video lectures" of online course includes 5 prerecorded video lectures. Lecturer use PowerPoint with the voiceover feature for creating online lectures. PowerPoint with voiceover is a tool which allows us to provide voice explanation of examples, tables, facts, graphs etc. The final result was being saved as a video in the mp4 file format. PowerPoint presentations (slides) of the lectures are also were posted on platform LIKAR_NMU, which can be useful for fast reminding the material.

Part "Seminars" of online course includes review and research articles (in Ukrainian and English), methodological instructions and question set for each topic. Modules where students uploaded their works (essays, presentations) are also presented here.

The posted materials on platform LIKAR_NMU we hope were provided to enhance students' understanding of the course (Cahyana et al., 2019).

Each seminar (according to the schedule) is occurred like videoconference via Zoom.

Social networks (Viber, Telegram and WhatsApp) are also used in educational process as an additional element of a course "Competency-based approach in Pharmacy education". The social media application is used in educational process for the encouraging information sharing among students, increasing the motivation of the students about the course, information sharing the documents related to a subject, instant answers to obscure topics.

\section{FINDINGS}

\section{A. Course Evaluation}

One hundred and sixty one students completed the course. One hundred and forty seven students $(91.3 \%)$ completed the anonymous voluntary 9-question post-course survey (Table II).

\section{B. Knowledge Assessment}

Number of students who received grades of A, B, C or D and $\mathrm{E}$ in the online elective course are shown in Table III. The most students earned an A and B.

TABLE III: NUMBER OF STUDENTS WHO RECEIVED GRADES OF A, B, C, D OR E IN ONLINE COURSE

\begin{tabular}{ccccc}
\hline \hline Grade & $\mathrm{A}(\%)$ & $\mathrm{B}(\%)$ & $\mathrm{C}(\%)$ & $\begin{array}{c}\mathrm{D} \text { and } \mathrm{E} \\
(\%)\end{array}$ \\
\hline \hline $\begin{array}{c}\text { Number of } \\
\text { students }\end{array}$ & $\begin{array}{c}107 \\
(66.1 \%)\end{array}$ & $\begin{array}{c}36 \\
(22.2 \%)\end{array}$ & $\begin{array}{c}19 \\
(11.7 \%)\end{array}$ & $0(0.0 \%)$ \\
\hline \hline
\end{tabular}

\section{DISCUSSION}

Overall, the responses to survey questions revealed a high percentage of students "agreed/strongly agreed" with positive statements about organizing the course and its quality (from 70.7 till $83.7 \%$ ).

Most of them reported that they would recommend this elective course to other students. Overall, students felt that the course was educational, engaging, and well organized with effective delivery of material.

But we will try to improve fullness of lectures and increase the number of English literature during the teaching of the course. The future plans are also to adopt this elective course for foreign (English-speaking) students of the first year of study of the pharmaceutical faculty at the Bogomolets National Medical University, and then to compare the attitude of foreign students and national students to the course.

Our data indicate that students earned grades A, B, C in online course format. This high level of the students' performance confirms that online education is the effective tool as well as face-to-face classes.

TABLE II: COURSE EVALUATION

\begin{tabular}{lcccc}
\hline \hline $\mathrm{N}$ & Statement & $\begin{array}{c}\text { Agree/strongly } \\
\text { agree, } \mathrm{n}(\%)\end{array}$ & $\begin{array}{c}\text { Neither agree } \\
\text { nor disagree, } \\
\mathrm{n}(\%)\end{array}$ & $\begin{array}{c}\text { Disagree/strongly } \\
\text { disagree, } \mathrm{n}(\%)\end{array}$ \\
\hline \hline 1 & Course is well organized & $104(70.8 \%)$ & $35(23.8 \%)$ & $8(5.4 \%)$ \\
2 & Course is with effective delivery of material & $106(72.1 \%)$ & $31(21.1 \%)$ & $10(6.8 \%)$ \\
3 & Course is very engaging & $115(78.2 \%)$ & $27(18.4 \%)$ & $5(3.4 \%)$ \\
4 & Course is useful for better understanding the future & $120(81.6 \%)$ & $20(13.6 \%)$ & $7(4.8 \%)$ \\
5 & pharmacists work & $104(70.7 \%)$ & $32(21.8 \%)$ & $11(7.5 \%)$ \\
6 & Video lectures are very informative & $105(71.4 \%)$ & $34(23.1 \%)$ & $8(5.5 \%)$ \\
7 & Video lectures are very interesting & $109(74.1 \%)$ & $28(19.1 \%)$ & $10(6.8 \%)$ \\
8 & The seminars are very interactive & $105(71.4 \%)$ & $35(23.8 \%)$ & $7(4.8 \%)$ \\
9 & I like the way of the delivery material by the lecturer & $123(83.7 \%)$ & $21(14.3 \%)$ & $3(2.0 \%)$ \\
\hline \hline
\end{tabular}




\section{CONCLUSION}

The online elective course "Competency-based approach in Pharmacy education" was successfully implemented during the first semester of 2020/2021 academic year for pharmacy students of the first year of study at the Bogomolets National Medical University. To achieve this goal the platform LIKAR_NMU on the basis of LMS Moodle together with video conferencing, pre-recorded video lectures and social software was used.

The elective course "Competency-based approach in Pharmacy education" enabled Ukrainian students to extend theoretical knowledge about competency-based approach in modern pharmacy education, to develop research and creative thinking skills. These are factors which are contributed to the formation of professional competency of future pharmacists. This elective course was successfully conducted achieving the desired learning outcomes and was well received by the students.

\section{REFERENCES}

Aldiab, A., Chowdhury, H., Kootsookos, A., Alam, F., \& Allhibi, H. (2019). Utilization of Learning Management Systems (LMSs) in higher education system: A case review for Saudi Arabia. Energy Procedia, 160, 731-737.

Cahyana, U., Supatmi, S., Erdawati, \& Rahmawati, Y. (2019). The Influence of Web-Based Learning and Learning Independence toward Student's Scientific Literacy in Chemistry Course. International Journal of Instruction, 12(4), 655-668. https://doi.org/10.29333/iji.2019.12442a.

De Mario, C., Limongelli, C., Sciarrone, F., \& Temperini, M. (2020). MoodleREC: A recommendation system for creating courses using the moodle e-learning platform. Computers in Human Behavior, 104, 106168. https://doi.org/10.1016/j.chb.2019.106168.

Dorovsky, O. V., \& Oliynyk, A. D. (2014). Pharmaceutical industry of Ukraine: the current state and directions of strategic development. Scientific Bulletin of the Kherson State University, 7, 75-78.

Eiben, H., Hala, L., \& Slipchuk, V. (2021). The current state of the pharmaceutical market of Ukraine, quality assurance and falfication of medicines. Pharmacia, 68(2), 411-419.

Hager, P., \& Gonczi, A. (1996). What is competence? Medical Teacher, 18(1), 15-18. http://doi.org/10.3109/01421599609040255.

Katoue, M. G., \& Schwinghammer, T. L. (2020). Competency-based education in pharmacy: A review of its development, applications, and challenges. Journal of Evaluation in Clinical Practice, 26(4), 11141123. https://doi.org/10.1111/jep.13362.

Koster, A., Schalekamp, T., \& Meijerman, I. (2017). Implementation of Competency-based Pharmacy Education (CBPE). Pharmacy, 5(10), 116. http://doi.org/doi:10.3390/pharmacy5010010.

Kuchyn, I. L., Vlasenko, O. M., Gashenko, I. A., Mykytenko, P. V., \& Kucherenko, I. I. (2021). Creating the informational and educational environment of the University based on the distance learning platform LIKAR_NMU. Archives of Pharmacy Practice, 12(2), 66-74. https://doi.org/10.51847/5zZerOAbwA.

Panfilova, H., Bogdan, N., Gala, L., Simonian, L., \& Tsurikova, O. (2018). Analysis of Ukrainian Pharmaceutical Market Retail Segment Development. Journal of Global Pharma Technology, 10(03), 191199. https://doi.org/10.3897/pharmacia.68.e64723.

Reva, T. (2016). Teoretychni kontsepty kompetentnisnoho pidkhodu u farmatsevtychnii osviti [Theoretical concepts of the competency-based approach in pharmaceutical education]. Continuing professional education: theory and practice (series: pedagogical sciences), 1-2(4647), 127-131 (in Ukrainian).

Reva, T. D. (2017). Prohrama elektyvnoho kursu "Kompetentnisnyi pidkhid u farmatsevtychnii osviti" yak obiekt pedahohichnoho proektuvannia [The programme of the elective course "The competency-based approach in pharmaceutical education" as a subject of pedagogical design]. Pedagogical Sciences, 1(87), 129-135 (in Ukrainian).
Sinha, H. K. (2014). Role of pharmacist in relating of drugs. Journal of Advanced Pharmaceutical Technology \& Research, 5(3), 107. http://doi.org:10.4103/2231-4040.137383.

Toklu, H. Z., \& Hussain, A. (2013). The changing face of pharmacy practice and the need for a new model of pharmacy education. Journal of Young Pharmacists, 5(2), 38-40. http://doi.org:10.1016/j.jyp.2012.09.001.

Widyaningsih, S. W., Yusuf, I., Prasetyo, Z. K., \& Istiyono, E. (2021). The Development of the HOTS Test of Physics Based on Modern Test Theory: Question Modeling through E-learning of Moodle LMS. International Journal of Instruction, 14(4), 51-68. https://doi.org/10.1016/j.egypro.2019.02.186. 